\begin{tabular}{|l|l|l||}
\hline \multicolumn{2}{|c|}{ PublisherInfo } \\
\hline \hline PublisherName & $:$ & BioMed Central \\
\hline \hline PublisherLocation & $:$ & London \\
\hline \hline PublisherImprintName & $:$ & BioMed Central \\
\hline \hline
\end{tabular}

\title{
1999 Additions to the SCCM Guidelines \& Practice Parameters
}

\begin{tabular}{|l|l|l||}
\hline \multicolumn{2}{|c||}{ ArticleInfo } \\
\hline \hline ArticleID & $:$ & 4226 \\
\hline \hline ArticleDOI & $:$ & $10.1186 /$ ccf-1999-webreport101 \\
\hline \hline ArticleCitationID & $:$ & webreport101 \\
\hline \hline ArticleSequenceNumber & $:$ & 14 \\
\hline \hline ArticleCategory & $:$ & Web report \\
\hline \hline ArticleFirstPage & $:$ & 1 \\
\hline \hline ArticleLastPage & $:$ & 2 \\
\hline \hline & & RegistrationDate : 1999-12-6 \\
ArticleHistory & $:$ & OnlineDate \\
\hline \hline ArticleCopyright & $:$ & Current Science Ltd1999-12-6 \\
\hline \hline ArticleGrants & $:$ & \\
\hline \hline ArticleContext & $:$ & 1305433 \\
\hline \hline
\end{tabular}




\section{Overview}

The site includes a section listing 11 consensus reports published as guidelines for various topics in critical care medicine, dating back to 1992. The 1999 additions include admission/discharge policies for pediatric intensive care units; recommendations about critical care services and personnel; and practice parameters for hemodynamic support of sepsis in adults.

\section{Content}

The 'Practice Parameters for Hemodynamic Support of Sepsis in Adult Patients' is an excellent review of this topic, commenting on fluid resuscitation, vasopressor therapy, and inotropic therapy. There are 197 references, some of which are rated using the Evidence-Based Medicine's rating system.

\section{Other comments}

The hemodynamic support of sepsis guideline is dated March 1999.

\section{Evaluation}

Freely available in the site.

\section{References}

1. Society of Critical Care Medicine. [http://sccm.org/accm/guidelines/guide_home_set.html]

This PDF file was created after publication. 